\title{
Weeds OccurRence in AReas Submitted to Distinct Winter CROPS $^{1}$
}

\author{
Ocorrência de Plantas Daninhas em Áreas Submetidas a Manejos de Inverno
}

\author{
CONCENÇO, G. ${ }^{2}$, SILVA, C.J. ${ }^{3}$, STAUT, L.A. ${ }^{4}$, PONTES, C.S. ${ }^{5}$, LAURINDO, L.C.A.S. ${ }^{5}$, and \\ SOUZA, N.C.D.S. ${ }^{5}$
}

\begin{abstract}
In the Western Region of Brazil, it is usual to have two agricultural harvests in the same cropping season. Usually the first crop is soybean, followed by corn. In areas where corn is not planted due to a delayed harvest of soybean, farmers generally do not use winter crops. For these areas, the planting of winter oilseed crops aiming at the production of biofuels is one of the best alternatives; in addition, this would help in reducing the occurrence of weed species at the following summer crop. This study aimed to assessing the weed community in distinct winter crops post soybean crop, in terms of species composition, level of infestation and severity of occurrence. The following treatments were evaluated: agriculture under a no-till system with winter fallow, winter oilseed crops (crambe, radish, rapeseed) with no-till agriculture in the summer, and agriculture under a conventional tillage system with winter fallow. Phytosociological evaluations of all treatments were carried out $75 \mathrm{DAE}$ of the oilseed crops, and the diversity indexes of Margalef, Menhinick, Simpson, and ShannonWeiner were determined. Areas were also grouped by cluster analysis based on UPGMA applied at Jaccard's similarity matrix. Among the treatments with winter coverage, radish was the most efficient crop in suppressing the occurrence of weed species. The area with conventional tillage agriculture and winter fallow allowed for a higher occurrence of troublesome weeds. On the other hand, the area under fallow showed the highest absolute level of infestation. Overall, oilseed crops in the winter contribute to lower levels of infestation by weed species in these areas.
\end{abstract}

Keywords: phytosociology; oilseed crops; infestation; Crambe abyssinica; Brassica napus; Raphanus sativus.

RESUMO - Na região Centro-Oeste do Brasil, é usual a obtenção de duas colheitas na mesma safra agrícola. Normalmente o primeiro cultivo é de soja, seguida por milho. Em áreas onde o milho não é cultivado devido à colheita tardia da soja, os produtores normalmente não utilizam culturas ou coberturas no periodo de inverno. Para essas áreas, o plantio de culturas oleaginosas de inverno visando à produção de biodiesel é uma das melhores alternativas; essa prática também auxiliará na redução da infestação por plantas daninhas no cultivo subsequente. Este estudo teve como foco a avaliação da comunidade infestante em áreas com distintas culturas de inverno, em termos de composição de espécies, nível de infestação e severidade de ocorrência. Os seguintes tratamentos foram avaliados: agricultura sob plantio direto com pousio no inverno; culturas oleaginosas de inverno (crambe, nabo, canola) pós-soja estabelecida em plantio direto no verão; e agricultura sob preparo convencional do solo com pousio no inverno. As análises fitossociológicas de todos os tratamentos foram conduzidas 75 dias após emergência (DAE) das culturas de inverno, e os indices de diversidade de espécies de Margalef, Menhinick, Simpsom e Shannon-Weiner foram calculados. As áreas também foram estratificadas por análise de agrupamento, pelo método UPGMA com base na matriz de similaridade de Jaccard. Dos tratamentos com cobertura de inverno, o nabo foi o mais eficiente em suprimir a ocorrência de plantas daninhas. A agricultura com preparo convencional do solo e pousio

Recebido para publicação em 5.2.2012 e aprovado em 16.5.2012.

Agronomist, D.Sc., Weed Science researcher at Embrapa Western Region Agriculture, Dourados-MS, Brazil, <germani@cpao.embrapa.br>; 3 Agronomist, D.Sc., Agro-Energy researcher at Embrapa Western Region Agriculture, DouradosMS, Brazil; ${ }^{4}$ Agronomist, M.Sc., Soil Science researcher at Embrapa Western Region Agriculture, Dourados-MS, Brazil; ${ }^{5}$ Undergraduate student in Agronomy, trainee at Embrapa Western Region Agriculture, Dourados-MS, Brazil.

Planta Daninha, Viçosa-MG, v. 30, n. 4, p. 747-755, 2012 
no inverno proporcionou a maior ocorrência de espécies daninhas problemáticas. Por outro lado, a agricultura em plantio direto com pousio no inverno apresentou o maior nível absoluto de infestação. Em termos gerais, culturas oleaginosas de inverno contribuem para reduzir a proliferação de espécies infestantes na entressafra.

Palavras-chave: fitossociologia, oleaginosas de inverno, infestação, Raphanus sativus, Brassica napus, Crambe abyssinica.

\section{INTRODUCTION}

In the western region of Brazil, it is usual to have two agricultural harvests in the same cropping season due to suitable environmental conditions. Due to a mild and dry winter, the first crop in this region may be planted as soon as the first monsoons allow for adequate soil moisture - usually in October (Fietz \& Rangel, 2008). Soybeans are usually planted as a main crop due to its higher profitability in comparison to corn. Soybeans planted during the first monsoons are harvested in late February or early March, when corn, the second crop, is immediately planted. The Brazilian Agricultural Research Corporation (Embrapa) recommends that corn should be planted as a second grain crop no later than March 10, when the estimated climatic scenarios start to depict very high possibilities of severe damage by both drought and frost at the flowering and grain filling stages (Lazzarotto, 2002).

In this scenario, areas are usually not used from the corn harvest (around July) until October. To avoid that, areas are left uncovered at this period when weeds would grow. Embrapa has developed the intercropping of corn with Brachiaria spp., which allows for similar yields in comparison to corn grown alone while leaving biomass on the soil during the winter (Ceccon, 2011).

If, on the one hand, research has proven there are relatively low risks and good yields to corn planted until March 10, on the other hand, the same crop planted one week later than the deadline may suffer severe damage by the previously described factors (Lazzarotto, 2002). As cropping areas are large in the region, farmers often are not able to plant soybeans throughout the totality of the area by the time of the first monsoons, thus corn may not be planted before March 10 in part of the area due to a late soybean harvest that does not allow soil tillage for the new planting in time.

In these areas where corn is not planted, farmers do not use winter crops leaving areas in fallow until the next monsoons. For these areas, winter oilseed crops aiming at the production of biofuels is one of the best alternatives, as for example crambe (Crambe abyssinica), radish (Raphanus sativus), and rapeseed (Brassica napus ). The use of these crops as winter coverage may be positive when all the benefits to the cropping system (mainly in terms of soil coverage and inhibition of weeds emergence) are considered. For example, hairy fleabane (Conyza bonariensis) resistant to the herbicide glyphosate is a troublesome weed in this region and its germination can be decreased by the presence of biomass at the soil surface (Vidal et al., 2007). In addition, the recent trend in growing these crops for biofuels will make them economically viable.

In addition, crambe and radish are known by the exudation of compounds with allelopathic effects to the soil (Grodzinsky, 1992; Spiassi et al., 2011), which could contribute significantly to the inhibition of weeds emergence. As the allelopathic compounds are more specific over given species, it is important to define which weed species are efficiently inhibited by the presence of these oilseed crops during winter.

Phytosociological studies allow for assessing the species composition of a given canopy and the estimation of frequency, relative frequency, abundance, relative abundance, dominance, relative dominance, and relative importance index for each species in the community, supporting inferences about a given group of plants (Gomes et al., 2010). In addition, it is possible to compare distinct areas under the same edaphoclimatic 
conditions by using Jaccard's similarity coefficient (Ferreira et al., 2008).

This study aimed to assess the weed community in distinct winter crops post soybean crop, in terms of species composition, level of infestation, and severity of occurrence.

\section{MATERIAL AND METHODS}

The experiment was performed under field conditions in the Embrapa Western Region Agriculture, Dourados, Mato Grosso do Sul State, Brazil, located at geographical coordinates $22^{\circ} 16^{\prime} \mathrm{S}$ and $54^{\circ} 49^{\prime} \mathrm{W}$ at $408 \mathrm{~m}$ above sea level. The trial was performed with a strip-plot experimental design (IRRI, 1993) with five replications. The plot dimension was $12 \mathrm{~m} \times 25$.

Treatments were composed by distinct winter crop management for the last year: (1) summer no tillage soybean crop followed by winter fallow; (2) crambe (Crambe abyssinica); (3) radish (Raphanus sativus); (4) rapeseed (Brassica napus); and (5) conventional soil tillage soybean crop followed by winter fallow. In the last treatment, right after soybean harvest, the area was lightly harrowed.

The oilseed crops were drill planted on May 26, 2011, in rows spaced at $0.40 \mathrm{~m}$. Fertilization was done only at planting by applying $347 \mathrm{~kg} \mathrm{ha}^{-1}$ of NPK 08-20-20 at the seeding furrow. There was no further management (weeds or pests control, fertilization) in the post-emergence of the crops.

Phytosociological characterization of the weed species emerged from the soil seed bank was carried out 75 days after emergence (DAE) in each one of the five areas. For that, the Random Quadrats method (Barbour et al., 1980) was used and 10 areas of $1 \mathrm{~m}^{2}$ in each management system were sampled. All the emerged seedlings were identified by species, collected and stored in paper bags in each sampled area, and dried in an oven with continuous air circulation for posterior dry mass determination.

Estimations of relative frequency, relative dominance, and relative abundance were done for each species present. These variables describe the relationship of each species with the others in the same area. The Importance Value Index (I.V.I.), which ranks species in terms of importance within the studied area, was also determined (Pandeya et al., 1968; Barbour et al., 1980):

Relative abundance: (abundance of the given species/total abundance of all species) $\mathrm{x} 100$.

Relative frequency: (frequency of the given species/total frequency of all species) x 100.

Relative dominance: (dry mass of the given species/total dry mass of all species) x 100 .

Importance Value Index: relative abundance + relative frequency + relative dominance.

Areas were also intra-characterized by the diversity coefficients of Margalef $(\alpha)$, Menhinick (Dm) (Krebs, 1989), Simpson (D) and modified Shannon-Weiner ( $\left.\mathrm{H}^{\prime}\right)$ (Barbour et al., 1980). After these analyses, the areas were compared by Jaccard's and Sørensen's presence-only similarity coefficients (Barbour et al., 1980) in a way to estimate the current degree of weeds similarity between areas after one year of distinct winter crops:

$$
\begin{aligned}
& \text { Margalef }(\alpha):(\mathrm{S}-1) /(\log \mathrm{N}) \\
& \text { Menhinick }(\mathrm{Dm}): \mathrm{S} / \operatorname{sqr}(\mathrm{N}) \\
& \text { Simpson }(\mathrm{D}): 1-\left(\Sigma \mathrm{n}_{\mathrm{i}}{ }^{*}\left(\mathrm{n}_{\mathrm{i}}-1\right) /\left(\mathrm{N}^{*}(\mathrm{~N}-1)\right)\right. \\
& \text { Shannon-Weiner }\left(\mathrm{H}^{\prime}\right): \Sigma \mathrm{p}_{\mathrm{i}}{ }^{*} \log \left(\mathrm{p}_{\mathrm{i}}\right)
\end{aligned}
$$

where $\mathrm{S}=$ total number of species at the community; $\mathrm{N}=$ total number of individuals sampled; $\mathrm{n}_{\mathrm{i}}=$ number of individuals from the species " $i$ "; $p_{i}=$ proportion of the species " $i$ ".

$$
\text { Jaccard (J): c/ (a+b-c) }
$$

Sørensen (S): 2c/( $a+b)$

where $\mathrm{a}=$ number of plant species at the area "a"; $b=$ number of plant species at area "b"; c = number of plant species common to areas "a" and "b".

Based on Jaccard's coefficient, areas were grouped by cluster analysis considering the qualitative trait only, according to Gower's algorithm (Gower, 1971). Hierarchical grouping 
was obtained from Jaccard's similarity matrix (Barbour et al., 1980) by using the Unweighted Pair Group Method with the Arithmetic Mean (UPGMA) method (Sneath \& Sokal, 1973). Threshold level for defining the number of groups was based on the simple mean of Jaccard's similarity matrix (Barbour et al., 1980). Grouping validation was accomplished by the cophenetic correlation coefficient (Sokal \& Rohlf, 1962).

\section{RESULTS AND DISCUSSION}

The number of weed plants for all the areas and their dry mass are shown in Figure 1. Treatments differed in terms of weeds infestation, being the area under fallow the one which presented the highest number of weed plants (Figure 1). Radish was the winter crop most capable of inhibiting the development of weed plants; probably this low infestation is due to its capacity of exudating allelopathic compounds. In addition, rapeseed is not characterized by presenting high allelopathic issues, but crambe is recognized by its ability to inhibit weeds appearance in a similar way to radish (Grodzinsky, 1992).

In this study, crambe plants had its initial development affected by a severe drought that caused delayed canopy development, allowing the weed plants that are less sensitive to water deficits to establish themselves. Moreover, crambe has a shorter phenological cycle than radish and rapeseed, and thus leaves were lost earlier allowing sun radiation to reach the soil. Another issue is that Crambe has a 90 day average cycle, which results in a long period after harvest where no coverage is left in the soil, thus allowing plants of weed species to develop and use the available physical space.

The conventional soybean area (T5) presented also a low number of weed plants in comparison to the areas with winter crops, except for radish (Figure 1). The dry mass of the weedy community also differed among treatments, but with a distinct behavior compared to the observed number of weed plants. For the no-till soybean with winter fallow area (T1), the dry mass of weedy species was about half of the total number of plants. This means that, on average, each weed plant weighed about $0.47 \mathrm{~g}$. Similar behavior was observed for the area where radish was used as a winter crop, where each plant weighed about $0.35 \mathrm{~g}$. In contrast to this, each weed plant weighed about $1.37,2.18$, and $2.11 \mathrm{~g}$, respectively, for areas grown with crambe, rapeseed, and summer conventional tillage soybean (T5) with winter fallow (Figure 1).

Both for the number of weed plants and for dry mass, the area grown with radish presented the lowest infestation. The number of weedy plants in the area with radish was about $12.6 \%$, $31.6 \%, 57.1 \%$, and $92.3 \%$ of the observed for notill fallow, crambe, rapeseed and conventional agriculture areas, respectively (Figure 1). For dry mass, the area grown with radish presented $7.1 \%, 6.6 \%, 4.9 \%$, and $10.0 \%$ of the observed for no-till fallow, crambe, rapeseed and conventional agriculture areas, respectively (Figure 1).

The number of species was $15,12,8,11$, and 9, respectively, for no-till fallow, crambe, radish, rapeseed and conventional agriculture areas, respectively (Tables 1, 2, 3, 4 and 5). The high number of species observed in the no-till fallow (Table 1) is in accordance with the high number of plants in the same area (Figure 1). On the other hand, the lowest number of weed species and dry mass occurred where the radish was grown (Table 3, Figure 1).

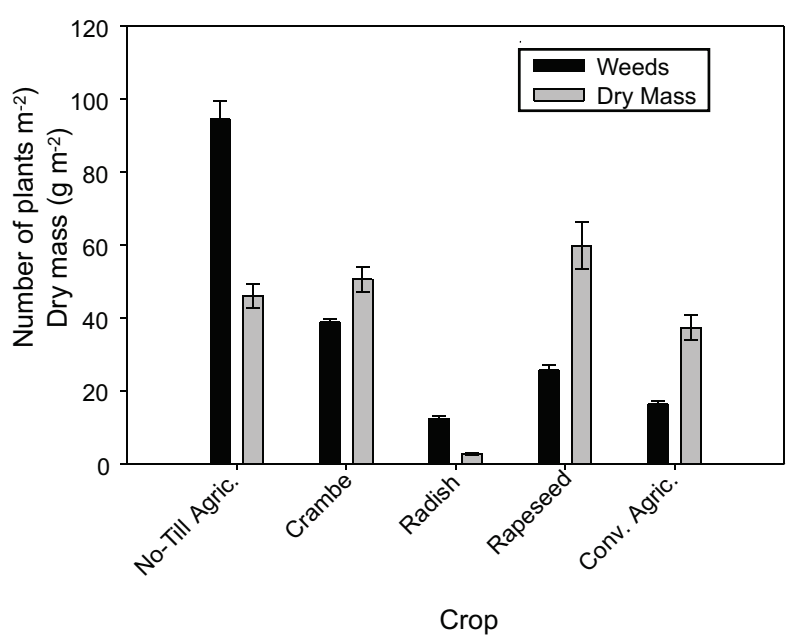

Figure 1 - Number of plants of weed species and dry mass of the weedy community as a function of the winter management of the area. Embrapa Agropecuária Oeste, Dourados-MS, 2011. 
Table 1 - Analysis of weed species and their importance in notill summer soybean area followed by winter fallow. Embrapa Western Region Agriculture, Dourados-MS, Brazil, 2011

\begin{tabular}{|l|c|c|c|c|}
\hline \multicolumn{1}{|c|}{ Species } & $\begin{array}{c}\text { Abund. } \\
(\%)\end{array}$ & $\begin{array}{c}\text { Freq. } \\
(\%)\end{array}$ & $\begin{array}{c}\text { Domin. } \\
(\%)\end{array}$ & I.V.I. \\
\hline Ageratum conyzoides & 1.3 & 2.1 & 4.4 & 7.8 \\
\hline Amaranthus deflexus & 5.9 & 6.4 & 0.7 & 13.0 \\
\hline Amaranthus hybridus & 5.1 & 6.4 & 0.1 & 11.6 \\
\hline Amaranthus viridis & 0.4 & 2.1 & 0.0 & 2.6 \\
\hline Avena sativa & 21.2 & 17.0 & 79.1 & 117.3 \\
\hline Bidens pilosa & 3.8 & 4.3 & 0.4 & 8.5 \\
\hline Commelina benghalensis & 0.4 & 2.1 & 0.0 & 2.6 \\
\hline Conyza bonariensis & 0.8 & 2.1 & 0.0 & 3.0 \\
\hline Coronopus didymus & 0.4 & 2.1 & 0.2 & 2.7 \\
\hline Hyptis suaveolens & 2.5 & 6.4 & 0.3 & 9.2 \\
\hline Leonotis nepetifolia & 4.7 & 6.4 & 0.7 & 11.7 \\
\hline Lepidium virginicum & 3.4 & 4.3 & 1.6 & 9.2 \\
\hline Richardia brasiliensis & 16.9 & 19.1 & 7.5 & 43.6 \\
\hline Sida rhombifolia & 31.8 & 12.8 & 4.1 & 48.7 \\
\hline Talinum paniculatum & 1.3 & 6.4 & 1.0 & 8.7 \\
\hline Total & 100 & 100 & 100 & 300 \\
\hline
\end{tabular}

Abund. $=$ abundance; Freq. $=$ frequency; Domin. $=$ dominance; I.V.I. = importance value index

Phytosociological analysis in the no-till fallow area (Table 1) showed that, in winter, Avena sativa was the most important weed species, mainly due to its high dominance over the other species, although it was the second most abundant and most frequent species. Even with a high number of species present, most of them are not adapted to the conditions of winter in Mato Grosso do Sul state (low abundance, frequency, and dominance), resulting in a lower importance for these species in lieu of Avena sativa when all characters are considered. A. sativa is highly abundant because it was sowed as winter coverage two years before the assembly of the trial, with no tillage allowing seeds to be produced and deposited at the soil seed bank. The infestation of this species is high both in areas where corn is planted as a second crop, as in the areas followed by fallow after soybeans. Even with low IVI and no dominance, the biotype of Conyza bonariensis, which is
Table 2 - Analysis of weed species and their importance in an area grown with crambe post-soybean as winter oilseed crop. Embrapa Western Region Agriculture, Dourados-MS, Brazil, 2011

\begin{tabular}{|l|r|r|r|r|}
\hline \multicolumn{1}{|c|}{ Species } & $\begin{array}{c}\text { Abund. } \\
(\%)\end{array}$ & $\begin{array}{c}\text { Freq. } \\
(\%)\end{array}$ & $\begin{array}{c}\text { Domin. } \\
(\%)\end{array}$ & I.V.I. \\
\hline Amaranthus deflexus & 8.2 & 8.2 & 1.4 & 17.8 \\
\hline Amaranthus hybridus & 3.1 & 3.1 & 0.1 & 6.2 \\
\hline Avena sativa & 33.7 & 33.7 & 80.0 & 147.4 \\
\hline Bidens pilosa & 6.1 & 6.1 & 0.4 & 12.7 \\
\hline Boerhavia diffusa & 2.0 & 2.0 & 0.1 & 4.2 \\
\hline Commelina benghalensis & 2.0 & 2.0 & 0.4 & 4.5 \\
\hline Coronopus didymus & 1.0 & 1.0 & 0.0 & 2.0 \\
\hline Euphorbia heterophylla & 1.0 & 1.0 & 0.2 & 2.2 \\
\hline Hyptis suaveolens & 1.0 & 1.0 & 0.0 & 2.1 \\
\hline Leonotis nepetifolia & 31.6 & 31.6 & 16.4 & 79.7 \\
\hline Richardia brasiliensis & 2.0 & 2.0 & 0.1 & 4.2 \\
\hline Sida rhombifolia & 8.2 & 8.2 & 0.9 & 17.2 \\
\hline Total & 100 & 100 & 100 & 300 \\
\hline
\end{tabular}

Abund. = abundance; Freq. $=$ frequency; Domin. $=$ dominance; I.V.I. = importance value index.

Table 3 - Analysis of weed species and their importance in an area grown with radish post-soybean as winter oilseed crop. Embrapa Western Region Agriculture, Dourados-MS, Brazil, 2011

\begin{tabular}{|c|c|c|c|c|}
\hline Species & $\begin{array}{c}\text { Abund. } \\
(\%)\end{array}$ & $\begin{array}{c}\text { Freq. } \\
(\%)\end{array}$ & $\begin{array}{c}\text { Domin. } \\
(\%)\end{array}$ & I.V.I. \\
\hline Ageratum conyzoides & 3.2 & 5.9 & 1.2 & 10.3 \\
\hline Amaranthus deflexus & 6.5 & 11.8 & 0.9 & 19.1 \\
\hline Avena sativa & 9.7 & 17.6 & 76.7 & 104.0 \\
\hline Commelina benghalensis & 3.2 & 5.9 & 0.0 & 9.1 \\
\hline Leonotis nepetifolia & 67.7 & 41.2 & 19.9 & 128.9 \\
\hline Richardia brasiliensis & 3.2 & 5.9 & 0.0 & 9.1 \\
\hline Sida rhombifolia & 3.2 & 5.9 & 0.0 & 9.1 \\
\hline Tridax procumbens & 3.2 & 5.9 & 1.3 & 10.4 \\
\hline Total & 100 & 100 & 100 & 300 \\
\hline
\end{tabular}

Abund. = abundance; Freq. $=$ frequency; Domin. = dominance; I.V.I. $=$ importance value index.

resistant to the herbicide glyphosate, was found only in fallow areas. This means that this species, although not being a problem in 
the winter due to its low dominance, is capable of producing seeds in winter to increase its occurrence.

Table 4 - Analysis of weed species and their importance in an area grown with rapeseed post-soybean as winter oilseed crop. Embrapa Western Region Agriculture, Dourados-MS, Brazil, 2011

\begin{tabular}{|l|r|r|r|r|}
\hline \multicolumn{1}{|c|}{ Species } & $\begin{array}{c}\text { Abund. } \\
(\%)\end{array}$ & $\begin{array}{c}\text { Freq. } \\
(\%)\end{array}$ & $\begin{array}{c}\text { Domin. } \\
(\%)\end{array}$ & I.V.I. \\
\hline Ageratum conyzoides & 7.8 & 11.5 & 0.6 & 20.0 \\
\hline Amaranthus deflexus & 3.1 & 7.7 & 0.1 & 10.9 \\
\hline Amaranthus hybridus & 3.1 & 3.8 & 0.0 & 7.0 \\
\hline Avena sativa & 35.9 & 23.1 & 78.4 & 137.4 \\
\hline Brachiaria decumbens & 1.6 & 3.8 & 0.1 & 5.5 \\
\hline Coronopus didymus & 4.7 & 3.8 & 3.0 & 11.5 \\
\hline Digitaria horizontalis & 1.6 & 3.8 & 0.0 & 5.4 \\
\hline Leonotis nepetifolia & 4.7 & 3.8 & 0.0 & 8.6 \\
\hline Richardia brasiliensis & 15.6 & 19.2 & 3.5 & 38.3 \\
\hline Sida rhombifolia & 17.2 & 15.4 & 14.1 & 46.7 \\
\hline Soliva pterosperma & 4.7 & 3.8 & 0.2 & 8.7 \\
\hline \multicolumn{1}{|c|}{ Total } & 100 & 100 & 100 & 300 \\
\hline
\end{tabular}

Abund. $=$ abundance; Freq. $=$ frequency; Domin. $=$ dominance; I.V.I. = importance value index

Table 5 - Analysis of weed species and their importance in an area grown with soybeans under conventional soil tillage system in summer, followed by winter fallow. Embrapa Western Region Agriculture, Dourados-MS, Brazil, 2011

\begin{tabular}{|l|c|c|c|c|}
\hline \multicolumn{1}{|c|}{ Species } & $\begin{array}{c}\text { Abund. } \\
(\%)\end{array}$ & $\begin{array}{c}\text { Freq. } \\
(\%)\end{array}$ & $\begin{array}{c}\text { Domin. } \\
(\%)\end{array}$ & I.V.I. \\
\hline Ageratum conyzoides & 2.3 & 4.8 & 11.7 & 18.8 \\
\hline Amaranthus hybridus & 9.1 & 4.8 & 0.0 & 13.9 \\
\hline Chamaesyce hirta & 11.4 & 4.8 & 0.1 & 16.2 \\
\hline Commelina benghalensis & 4.5 & 9.5 & 1.9 & 16.0 \\
\hline Digitaria horizontalis & 2.3 & 4.8 & 2.8 & 9.8 \\
\hline Lepidium virginicum & 29.5 & 23.8 & 54.8 & 108.1 \\
\hline Richardia brasiliensis & 15.9 & 14.3 & 3.5 & 33.7 \\
\hline Sida rhombifolia & 22.7 & 28.6 & 25.2 & 76.5 \\
\hline Talinum paniculatum & 2.3 & 4.8 & 0.0 & 7.0 \\
\hline \multicolumn{1}{|c|}{ Total } & 100 & 100 & 100 & 300 \\
\hline
\end{tabular}

Abund. $=$ abundance; Freq. $=$ frequency; Domin. $=$ dominance; I.V.I. = importance value index.
Weed species composition in crambe is shown in Table 2. Avena sativa was the most important with IVI of 147.4. Leonotis nepetifolia was also important in this area due mainly to its abundance (number of individuals) and frequency (distributed all over the area). The remainder of the observed species did not highlight in any of the attributes quantified: they are in general terms similar in the number of individuals, distribution in the area and showed low dominance in comparison to Avena sativa and Leonotis nepetifolia (Table 2).

The area where radish was grown (Table 3) showed the least number of species among the treatments. A. sativa and L. nepetifolia are highlighted as the most important weed species, but while $A$. sativa is highlighted due to its high dominance, L. nepetifolia presented high abundance and frequency. This species was responsible for $67 \%$ of the total number of plants in the area. The sum of all other species was 33\% for the total plants in the area (Table $3)$. In contrast to the abundance, only $19 \%$ of the dominance was attributed to L. nepetifolia.

Infestation in rapeseed was more balanced in comparison to the previous treatments, with an abundance of $36 \%, 15 \%$, and $17 \%$, respectively, for A. sativa, Richardia brasiliensis and Sida rhombifolia (Table 4). A similar tendency was observed for the frequency of these species, while $78 \%$ of the dominance was attributed to A. sativa (Table 4). The three previously cited species were the ones with the highest IVI in rapeseed crop.

In the area with conventional agriculture during the summer and no winter cropping (Table 5), A. sativa was not detected, while it was the most important weed species in all other treatments. This probably happened because, at the conventional area, A. sativa is not used as a winter crop, so no seeds were present at the soil seed bank. The majority of the infestation was due to Coronopus didymus, followed by Sida rhombifolia and Richardia brasiliensis. C. didymus is usually a species with a low competitive ability against crop plants, although in the winter it can turn into an important weed species against slow-growing crops (Kissmann \& Groth, 1999). S. rhombifolia is a highly aggressive weed species in a wide range of environments, from agriculture to cattle raising, being also 
troublesome to the mechanical harvest due to its hard-to-break stem (Kissmann \& Groth, 1999).

Two of the major species in the summer conventional agriculture, followed by winter fallow (Table 5) are important weeds not easily controlled: S. rhombifolia, due to its resistant stem and strong root system, which is especially important in no-till areas, and $R$. brasiliensis due to its high tolerance to the herbicide glyphosate. It is also important to note the presence of Bidens pilosa, as an important weed species with cross resistance to several ALS inhibiting herbicides, in areas under fallow (Table 1) and crambe (Table 2), due to the small canopy formed by this crop in comparison to radish and rapeseed. On the other hand, S. rhombifolia was detected in different levels of importance in all treatments (Tables 1 to 5). Another important weed species with high tolerance to glyphosate is Commelina benghalensis, which was only absent from the rapeseed area.

A diversity index is a statistic that is intended to understand the variety of individuals of a given population (Barbour et al., 1980). A similar behavior was observed among all indexes (Table 6), except for Dm. In addition, $\alpha$ and ' $H^{\prime}$ showed to be more sensitive than Simpson's D in differentiating the areas. Giavelli et al. (1986) state that D is less prone to errors due to factors related to sampling problems, and should be chosen instead of H', and $\alpha$ was reported by a notable statistical imprecision. Simpson's D relates

Table 6 - Diversity indexes in areas with distinct winter management. Embrapa Western Region Agriculture, Dourados-MS, Brazil, 2011

\begin{tabular}{|l|c|c|c|c|}
\hline & $\alpha$ & $\mathrm{Dm}$ & $\mathrm{D}$ & $\mathrm{H}^{\prime}$ \\
\hline No-Till Agric. & 5.89 & 0.98 & 0.82 & 2.89 \\
\hline Crambe & 5.52 & 1.21 & 0.77 & 2.58 \\
\hline Radish & 4.69 & 1.43 & 0.54 & 1.75 \\
\hline Rapeseed & 5.53 & 1.37 & 0.81 & 2.79 \\
\hline Conv. Agric. & 4.86 & 1.35 & 0.83 & 2.67 \\
\hline
\end{tabular}

Indexes: $\alpha=$ Margalef; $\mathrm{Dm}=$ Menhinick; $\mathrm{D}=$ Simpson; $\mathrm{H}^{\prime}=$ Shannon-Weiner. the probability of two randomly selected individuals from an infinitely large community to belong to different species (Simpson, 1949). The Simpson index considers the abundance of species in the sample while being less sensitive to species richness (Simpson, 1949; Barbour et al., 1980). According to Simpson's $\mathrm{D}$, there was a small variation in diversity among treatments, being only possible to highlight a smaller diversity at the area grown with radish (Table 6). This area also presented the smaller number of plants (Figure 1) and weed species richness (Table 3).

Sørensen's and Jaccard's similarity coefficients are useful for comparing distinct areas in terms of species composition. None of them considers the number of individuals among the areas (Barbour et al., 1980). As Sørensen and Jaccard presented equivalent tendencies based on the raw data of the trial (Figure 2) only Jaccard's will be discussed. Felfili \& Venturoli (2000) suggest that the fixed value of 0.50 should be used as similarity indicator, while Looman \& Campbell (1960) suggested that these coefficients should be interpreted in an empirical way. In this study, the absolute mean of Jaccard's similarity matrix was used as the threshold level for defining groups.

Jaccard's matrix was calculated based on plant species occurrence, and cluster analysis (Figure 3) was established by the UPGMA method, with the threshold level established by the matrix mean criteria, and showed three distinct groups in terms of weeds occurrence. The first group was formed by radish alone, with low plant diversity and infestation, reflecting the capacity of this species in inhibiting the occurrence of weed species due to allelopathic issues. The second group was formed by rapeseed, conventional summer agriculture, and crambe, characterized by a reduced infestation and higher number of species. The third group was represented by summer direct seeding agriculture with winter fallow, with high plant diversity and levels of infestation (Figure 3). These data are according to the raw data presented in Figure 1.

After one year of distinct winter cropping management, there are remarkable differences both at the level of infestation and species composition between areas 


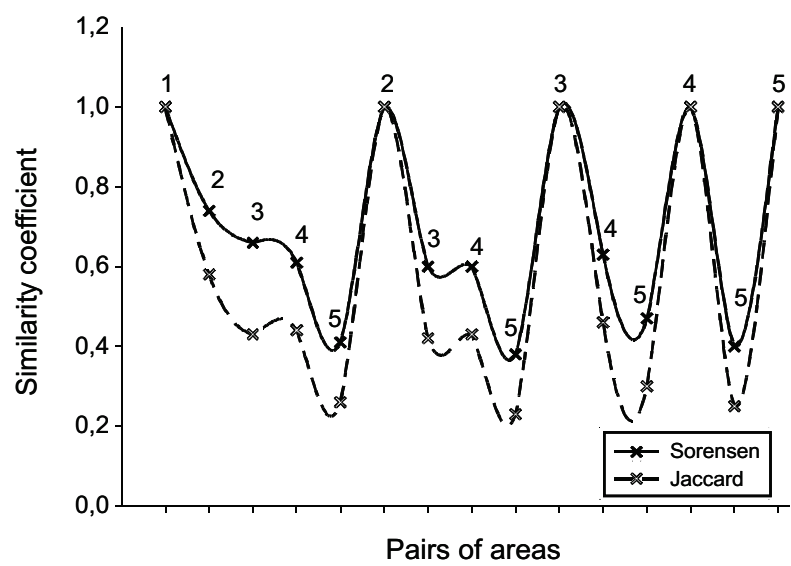

Figure 2 - Similarity coefficients of Sørensen and Jaccard comparing pairs of areas. Each peak identifies the beginning of comparison of an area with the subsequent ones. The greater the distance between the lines, the bigger the difference between the area of the peak numbered immediately at the left and the area where the space was quantified. Embrapa Western Region Agriculture, Dourados-MS, Brazil, 2011.

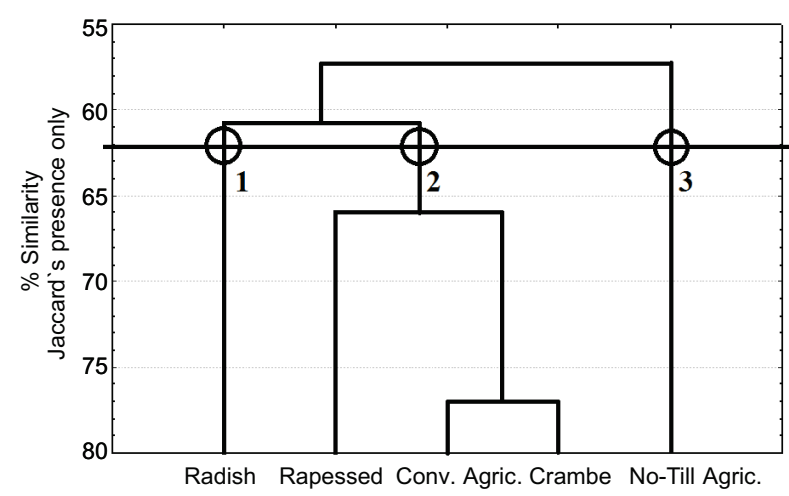

Figure 3 - Cluster analysis for five areas submitted to distinct managements. Threshold level of $62.1 \%$ was based on the criteria of mean of Jaccard's matrix, disregarding matching crosses between the same areas. Grouping was established based on the UPGMA method. Embrapa Western Region Agriculture, Dourados-MS, Brazil, 2011.

with and without winter coverage. As the composition of the soil seed bank was not significantly changed by a single year of distinct management (based on studies from other authors), discrepancies in infestation among areas were attributed solely to the differential management adopted.
In summary, among the treatments with winter coverage, radish was the most efficient crop in suppressing the occurrence of plants of weed species. In addition, the diversity of species was only reduced in the radish area. The area with conventional tillage agriculture with no winter cropping allowed for a higher occurrence of troublesome weeds such as Sida rhombifolia, Richardia brasiliensis and Commelina benghalensis. On the other hand, the area with no tillage agriculture followed by fallow presented the highest absolute level of weed infestation. Overall, the presence of oilseed crops in the winter contribute to a lower level of weeds infestation.

\section{ACKNOWLEDGEMENTS}

The financial support granted for this research by the Mato Grosso do Sul Foundation for the Development, Teaching, Science and Technology (FUNDECT) is gratefully acknowledged.

\section{LITERATURE CITED}

BARBOUR, M. G.; BURK, J. H.; PITTS, W. D. Terrestrial plant ecology. Menlo Park: Benjamin/Cummings, 1980. $604 \mathrm{p}$.

CECCON, G. Dicas para implantação do consórcio milhobraquiária. R. Plantio Direto, v. 124, n.1, p. 20-21, 2011.

FELFILI, J. M.; VENTUROLI, F. Tópicos em análise de vegetação. Brasília: Universidade de Brasília, 2000. 34 p. (Comunicações Técnicas Florestais, v.2, n.2).

FERREIRA, R. L. C. et al. Comparação de duas metodologias multivariadas no estudo de similaridade entre fragmentos de Floresta Atlântica. R. Árvore, v. 32, n. 3, p. 511-521, 2008.

FIETZ, C. R.; RANGEL, M. A. S. Época de semeadura da soja para a região de Dourados - MS, com base na deficiência hídrica e no fotoperíodo. Eng. Agríc., v. 28, n. 4, p. 666-672, 2008 .

GIAVELLI, G.; ROSSI, O.; SARTORE, F. Comparative evaluation of four species diversity indices related to two specific ecological situations. Field Studies, v. 6, n. 3, p. 429-438, 1986.

GOMES, G. L. G. C. et al. Cadastramento fitossociológico de plantas daninhas na bananicultura. Planta Daninha, v. 28, n. 1, p. 61-68, 2010. 
GOWER, J. C. A general coefficient of similarity and some of its properties. Biometrics, v. 27, n. 4, p. 857-874, 1971.

GRODZINSKY, A. M. Allelopathic effects of cruciferous plants in crop rotation. In: RIZVI, S. J. H.; RIZVI, V. (Eds.). Allelopathy. New York: Chapman \& Hall, 1992. p. 77-85.

IRRI. Irristat v.3.1. Los Baños: 1993.

KISSMANN, K.; GROTH, D. Plantas infestantes e nocivas. 2.ed. São Paulo: BASF, 1999. 722 p.

KREBS, C. J. Ecological methodology. New York: Harper Collins, 1989. 654 p.

LAZZAROTTO, C. Época de semeadura e riscos climáticos para o milho da safra outono-inverno, no Sul de Mato Grosso do Sul. Dourados: Embrapa Agropecuária Oeste, 2002. 4 p. (Embrapa Agropecuária Oeste. Comunicado Técnico, 70).

LOOMAN, J.; CAMPBELL, J. B. Adaptation of Sørensen's $\mathrm{K}$ (1948) for estimating unit affinities in prairie vegetation. Ecology, v. 41, n. 3, p. 409-416, 1960.
PANDEYA, S. C.; PURI, G. S.; SINGH, J. S. Research methods in plant ecology. New York: Asia Publishing House, 1968. 272 p.

SIMPSON, E. H. Measurement of diversity. Nature, v. 163, n. 4148 , p. $688,1949$.

SNEATH, P. H.; SOKAL, R. R. Numerical taxonomy: the principles and practice of numerical classification. San Francisco: W. H. Freeman, 1973. 573 p.

SOKAL, R. R.; ROHLF, F. J. The comparison of dendrograms by objective methods. Taxon, v. 11, n. 1, p. 33-40, 1962.

SPIASSI, A. et al. Alelopatia de palhadas de coberturas de inverno sobre o crescimento inicial de milho. Semina, v. 32, n. 2, p. 577-582, 2011.

VIDAL, R. A. et al. Impacto da temperatura, irradiância e profundidade das sementes na emergência e germinação de Conyza bonariensis e Conyza canadensis resistentes ao glyphosate. Planta Daninha, v. 25, n. 2, p. 309-315, 2007. 